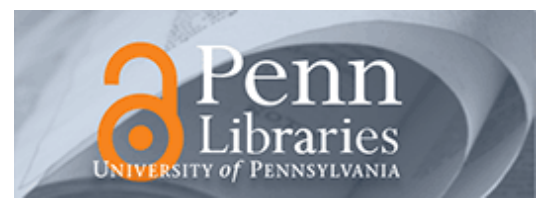

University of Pennsylvania

ScholarlyCommons

Real Estate Papers

Wharton Faculty Research

$7-2010$

\title{
Is SARS a Poor Man's Disease? Socioeconomic Status and Risk Factors for SARS Transmission
}

Grace Wong Bucchianeri

University of Pennsylvania

Follow this and additional works at: https://repository.upenn.edu/real-estate_papers

Part of the Other Business Commons, and the Real Estate Commons

\section{Recommended Citation}

Bucchianeri, G. (2010). Is SARS a Poor Man's Disease? Socioeconomic Status and Risk Factors for SARS Transmission. Forum for Health Economics \& Policy, 13 (2), http://dx.doi.org/10.2202/1558-9544.1209

This paper is posted at ScholarlyCommons. https://repository.upenn.edu/real-estate_papers/72

For more information, please contact repository@pobox.upenn.edu. 


\title{
Is SARS a Poor Man's Disease? Socioeconomic Status and Risk Factors for SARS Transmission
}

\author{
Abstract \\ various measures of income, but not years of education, unlike previous studies on other health \\ These results have implications for the understanding of the SES-health link in the context of a \\ strategies.

\section{Keywords} \\ socioeconomic status, infectious diseases, health, SARS, SES, health gradient \\ Disciplines \\ Other Business | Real Estate
}

This paper investigates the link between various risk factors, including socioeconomic status (SES), and the spread of Severe Acute Respiratory Syndrome (SARS) in Hong Kong in 2003. A comprehensive data set compiled by the author shows a negative and significant correlation between SARS incidence and conditions. The income-SARS gradient can be accounted for by controlling for pre-SARS housing values but not an array of measurable living conditions. Areas with more white-collar workers experienced a higher incidence rate, largely driven by the share of service and sales workers, after controlling for SES. contagious disease, the potential causality of the SES-SARS relationship and for future SARS containment 


\section{Forum for Health Economics \& Policy}

Volume 13, Issue 2

2010

Article 10

(HEALTH ECONOMICS)

\section{Is SARS a Poor Man's Disease? Socioeconomic Status and Risk Factors for SARS Transmission}

Grace Wong Bucchianeri* 


\title{
Is SARS a Poor Man's Disease? Socioeconomic Status and Risk Factors for SARS Transmission*
}

\author{
Grace Wong Bucchianeri
}

\begin{abstract}
This paper investigates the link between various risk factors, including socioeconomic status (SES), and the spread of Severe Acute Respiratory Syndrome (SARS) in Hong Kong in 2003. A comprehensive data set compiled by the author shows a negative and significant correlation between SARS incidence and various measures of income, but not years of education, unlike previous studies on other health conditions. The income-SARS gradient can be accounted for by controlling for pre-SARS housing values but not an array of measurable living conditions. Areas with more white-collar workers experienced a higher incidence rate, largely driven by the share of service and sales workers, after controlling for SES. These results have implications for the understanding of the SES-health link in the context of a contagious disease, the potential causality of the SES-SARS relationship and for future SARS containment strategies.
\end{abstract}

KEYWORDS: socioeconomic status, infectious diseases, health, SARS, SES, health gradient

\footnotetext{
*Also published under the name Grace Wong. I thank Alan Krueger and Ceci Rouse for continuous support and guidance, and Tsur Sommerville for providing me his 1993-1999 Hong Kong housing prices data. I have benefited from detailed discussions with Ted Miguel and Jesse Rothstein, and comments from numerous participants at the Princeton Labor Seminar. Eugene Brusilovskiy, Jennifer Chu, Yanshu Guo, Anna Huang, Steph Hsiao, Alexandra Infeld and Rachel Wong provided excellent research assistance. The Hong Kong Department of Health has been particularly helpful with my enquiries. Financial support from the Princeton University Industrial Relations Section, the Mellon Foundation/ Research Program in Development Studies and the Wharton Zell-Lurie Real Estate Center is gratefully acknowledged.
} 
Bucchianeri: Is SARS a Poor Man's Disease?

\section{Introduction}

The link between socioeconomic status (SES) and health is robust and welldocumented in many branches of social science, using numerous measures of health status. Questions remain in two areas: first, the direction of causation of any specific SES-health link, and second, the relative importance of different SES-health channels among different health measures and subsequent welfare policy implications (Goldman, 2001; Deaton, 2002; Currie and Stabile, 2003; Meer et al., 2003). This paper studies and offer insight into both questions by studying the 2003 outbreak of Severe Acute Respiratory Syndrome (SARS).

The SARS outbreak provides a unique setting to study the direction of causality of the SES-health relationship in the context of a contagious disease: it was an unanticipated outbreak of a previously unknown disease and therefore can be thought of as an exogenous shock; moreover, there is no evidence linking its prevalence to that of other illnesses, alleviating concerns about identification. So far, related research on SARS has focused on genetic, not economic or social, differences and factors affecting individuals' susceptibility are still being debated (Skowronski et al. 2005). There exists no evidence on the size or sign of any SESSARS gradient and no public health measure was taken with explicit consideration of such a link during or after the 2003 epidemic. ${ }^{1}$ This paper also adds to our knowledge about the spread of SARS in relation to living conditions. Undoubtedly, an understanding of the spread of SARS - a disease with epidemic potential and no cure - has important policy implications.

I use a compilation of hand-collected datasets from the most severely hit city in the 2003 epidemic, Hong Kong. ${ }^{2}$ Both the significant variation in the SARS incidence rate across the 18 districts in Hong Kong (Figure 1; Table 1A) and the negative correlation between the incidence of SARS and median income levels suggest a link between SES and the spread of SARS. ${ }^{3}$ First and foremost, this paper fills the gap in data availability by providing an estimate of the SARS incidence rate at a sub-district level for 295 large-scale housing complexes (known as estates) in Hong Kong. It then analyzes the SES-SARS link at an intra-

\footnotetext{
${ }^{1}$ According to the WHO, SARS risk factors include close contact to SARS cases, a low baseline health status and environmental contamination. There has been no mention of a direct SES-SARS link.

2 The SARS incidence rate in Hong Kong, at 0.258 per thousand, was the highest among all SARS-affected cities (World Health Organization, 2003). There were 299 SARS deaths in Hong Kong, accounting for more than a third of all SARS deaths.

${ }^{3}$ Regressing the SARS incidence rate on district fixed effects shows that there was no clear dichotomy of geographical areas into high- or low-risk districts. Section 6 provides more details.
} 
city level using a Tobit model. ${ }^{4}$ The mediating role of various SES indicators and living conditions is explored.

The 2003 SARS epidemic illustrates the type of low-probability, high-cost threat of infectious disease that is expected to become increasingly common in a more integrated world economy. During the 2003 epidemic (March-June), 8,096 people were infected, 774 lives were lost, and the economic cost in terms of lost GDP for East and Southeast Asian countries is estimated to be US\$18 billion (Asian Development Bank, 2003a). Threats of epidemic outbreaks like SARS are contained in an international effort by means of information sharing, public education, surveillance, and intensive tracing and home confinement of disease victims and their close contacts. These actions involve a large government effort and, as with any highly communicable disease, the externalities are high (WHO, 2003). Knowing which population segments are most vulnerable to diseases like SARS should be an important part of the containment strategy. Estimating the SES-SARS gradient can also provide insights into the spread of infectious diseases, and more generally the income-mortality gradient, in a region that is often predicted to be the origin of future epidemics (Loh, 2004). The SES-SARS link, causal or not, has direct implications on the optimal public health strategies on surveillance and disease containment.

The complex SES-health link has fueled debates over health care policy (Deaton, 2002; Meer et al., 2003). In addition to a direct casual impact of SES on health, a SES-health link can be a result of differential access to health care, variation in awareness or health-related behavior, or the impact of health on SES. Each of these channels has varying policy implications (Deaton, 2002). This paper speaks specifically to the link between SES and SARS, with potential implications for other infectious diseases. Several characteristics of the SARS epidemic suggest that more can be said about the nature of a SES-SARS link in Hong Kong, compared to a more general SES-health relationship. Firstly, vigorous epidemic measures and assignment of all SARS patients to specific restricted access wards minimized the difference in quality of epidemic control measures among subpopulations of different SES. Secondly, Lau et al. (2003) find that appropriate precautionary measures were practiced by over 90 percent of the Hong Kong population during the SARS epidemic, implying a low level of variation in preventative health behavior. ${ }^{5}$ Thirdly, because SARS was a newly

\footnotetext{
${ }_{5}^{4}$ The assumptions behind the Tobit model are discussed in the Appendix.

${ }^{5}$ The measures include mask wearing, frequent hand washing, avoidance of crowded places and the disinfection of living quarters. While the educated or healthcare professionals might be expected to adopt precautionary measures more efficiently, a survey of community doctors (General Practitioners, or GPs) reveals that some clinical practices such as frequent hand washing between patients were not followed. (Lau et al., 2003)
} 
discovered disease, a measure of historical SES status before the epidemic reflects little or no sorting behavior related to SARS. There is no evidence that susceptibility to SARS is related to that of other infectious diseases or to medical history. The SES measures used in this paper are pre-epidemic variables, which help circumvent a potential problem of reverse causality. ${ }^{6}$

In identifying a SES-SARS link, three measures of SES are utilized: income, education and occupation. Income exhibits the most robust relationship with the spread of SARS, which is independent from that between occupation and the spread of SARS. The lack of an education-SARS link contrasts with the education-health gradient identified in the literature for other health status measures (Deaton, 2002; Schnittker, 2004). It resonates with the findings of Tang and Wong (2003) that the adoption of preventive health behaviors during the SARS epidemic increased due to perceived susceptibility, self-efficacy and age but not education. This also suggests that our knowledge about the general SEShealth link might not be directly applicable to an epidemic situation such as SARS.

Using data on pre-SARS housing sales, rental prices and living conditions, I find that both permanent income and living conditions can explain at least part of the income-SARS correlation. When controlling for housing sales or rental prices, the income-SARS link becomes insignificant while the occupation-SARS link remains robust. This is consistent with the view that occupations relate to SARS incidence through channels such as contact with the public, other than through a pure income effect. I further explore the importance of various measurable living conditions, which in their own right are of interest. Estates with a higher number of floors per building and facilities such as health clubs or childcare centers experienced a higher incidence rate, possibly through environmental contamination (e.g., elevators) and a meeting-point effect. So did estates with a higher proportion of students and workers using public transportation, again pointing to an effect of social interaction. On the other hand, household crowding, proximity of health care establishments, building age and public or private ownership display no systematic relationship with the SARS incidence rate. Clearly, the data available is not ideal for identifying precise and causal relationships between each measure of living conditions with the spread of SARS, since it does not capture detailed property characteristics (such as the quality of plumbing infrastructure) or social interactions directly. Nevertheless, my analysis provides a basis for future research.

Even when controlling for all relevant measures of housing conditions, the income-SARS correlation remains stable and robust. Comparing this result to the

\footnotetext{
${ }^{6}$ In related work, Wong (2004) explores the impact of SARS on the housing market and finds a significant effect of SARS on housing values.
} 
case when both income and housing price are included in the model suggests that factors aside from living conditions that are related to housing prices - such as permanent income and non-housing consumption - contribute to the incomeSARS link. Lastly, I find no evidence that income inequality or homeownership explains intra-city variations of the income-SARS link.

This paper is organized as follows: the next two sections provide an epidemiology of SARS and a timeline of the epidemic in Hong Kong; Section 4 reviews related literature; Section 5 describes the data; Section 6 presents empirical findings and Section 7 concludes.

\section{SARS Epidemiology}

The causative agent of SARS is a newly identified coronavirus (SARS-CoV) that is sufficiently infectious to cause a very large epidemic if unchecked, but controllable with public health measures such as early detection, quarantine and treatment of SARS patients. On average, 2 to 4 people are infected by each SARS patient in the absence of any control measures.

Transmission mechanism of SARS is through deposit of virus through respiratory exudates and contaminated surfaces on membranes of mouth, nose or eyes. The risk of transmission increases within confined spaces, such as elevators and airplanes. Environmental factors such as sanitation and density are likely to have played a role in some outbreaks (Lipstitch et al., 2003; Riley et al., 2003; Hong Kong Department of Health, 2003; WHO, 2003).

Effective epidemic control measures include reduction of population contact rate, promotion of personal and environmental hygiene (frequent handwashing, mask wearing and disinfecting living quarters and shared facilities such as elevators), and detection and isolation of SARS cases.

It is not yet clear why some virus-carriers demonstrated higher-thannormal infectivity in "super-spreading events" (SSEs), where single individuals infected as many as 300 others (Dye and Gay, 2003; Lipsitch et al., (2003); Riley et al., 2003). Possible explanations include mutated strains of the virus, differences in modes of transmission and a much skewed population contact rate distribution. For comparability I have excluded the three SSEs from my sample. None of the SSEs are outliers in the SES distributions.

\section{Timeline of the 2003 SARS Epidemic in Hong Kong}

The first SARS cases in Hong Kong are now known to have occurred in February 2003. Figure 2 shows a timeline. At least 125 people were infected around March 3, 2003 in the Prince of Wales Hospital, forming the first SARS cluster (Riley et al., 2003). When seven residents in Block E of Amoy Gardens, a high-density 
Bucchianeri: Is SARS a Poor Man's Disease?

private housing estate, were diagnosed with SARS on March 26, 2003, the community transmission of the disease - i.e., its spread in the local community outside the group of close medical and family contacts of SARS patients - was confirmed by the government.

After the Amoy outbreak, there was a large-scale shutdown of normal activities. Most people either stayed at home or wore surgical masks, while all schools were suspended on March 29 for more than 3 weeks. Residents were infected across the board, including the educated, the young and the previously healthy. A high level of vigilance was displayed by the government and international organizations. Specific restrict-access SARS wards were set up to isolate all known SARS cases.

After three months, the epidemic was declared contained on June 23, 2003, 21 days after the last case in the territory was isolated. 1,755 people in Hong Kong were infected and 300 died from the disease. Less than a quarter of the SARS cases in Hong Kong were healthcare workers and most of the almost 400 infected residents in Amoy Gardens were strangers to each other. ${ }^{7}$

\section{Literature on the SES-Health Gradient and the spread of SARS}

There is a large body of literature demonstrating the positive variation in health status by socioeconomic status (SES). Feinstein (1993) and Goldman (2001) provide a detailed review of the related studies. Below, I outline three related main themes, each of which has implications for a potential SES-SARS link.

First, the variation of health status by SES is gradual and it exists at all levels of SES, not just limited to a poverty effect due to deprivation. Therefore there is ample interest in studies of the SES-health link in relatively affluent societies. They include the Whitehall studies (Marmot et al., 1984, 1991, 1995) that focus on British civil servants, none of whom is poor. Rogot et al. (1992) find a proportional income-mortality relationship that is constant at all income levels. In the case of SARS, the two most affected cities in the world are Hong Kong and Toronto, both developed and affluent. Based on previous literature, there might still exist an income or SES gradient within a developed city of a population well above subsistence.

Second, some form of a positive SES-health relationship emerges regardless of the choice of measurement of the SES, including income, education and occupation, and the country studied. Health measures, however, are shown to have relationships of different strength with different SES indicators (e.g., Hurd et al., 2003). This paper furthers this comparison. While various SES indicators are

\footnotetext{
${ }^{7}$ Source: The Standard; Oriental Daily; WHO website.
} 
correlated by definition, it is significant for both social scientists and for public policy makers to understand the varying importance of different SES indicators.

Third, recent studies provide some evidence that the observed SES-health relationship is more than a reverse causal impact of health on SES, i.e., people in poor health drift towards the bottom of the SES distribution, or a third factor effect, where factors such as height affect both income and health later in life (Goldman, 2001). The direction of causality, however, is not well identified in most studies, and this paper aims to help shed light on the subject.

Clearly, the SARS epidemic was a specific episode involving a newly discovered disease that elicited fear from the general population and emergency responses from the government and public organization. This means that what we know so far about the general SES-health link might not apply to a SARS epidemic. At the same time, the SES-SARS relationship should be interpreted as a case study of the more general SES-health link, instead of as generalizable evidence of a universal link.

Conceptually, it is not clear how SES might relate to the spread of SARS. On one hand, the positive gradient between income and health that has been found in previous research might lead one to expect the higher income and better educated groups to be at lower risk. This can be a result of more investment in health prior to SARS, better nutrition, more ready access to information or greater ability to adopt health behaviors (including exiting the affected areas). On the other hand, higher income groups might be under greater stress or have occupations that involve more contact with the public.

\section{Data}

\section{A. SARS Incidence Rate}

Although disaggregate data on the number of SARS cases below the district level are not recorded, the Hong Kong Department of Health provided the total number of cases in the territory and the number of cases in the three SSE sites with the largest clustering of cases. A daily "List of Buildings of Confirmed SARS Cases" (SARS-list henceforth), published by the Department of Health during the epidemic, contained addresses (up to the building level) of all SARS-affected sites on that day. ${ }^{8}$ I estimate the number of SARS cases in each housing estate by counting the number of times any building within each housing estate was put on the SARS-list, and then multiplying the number by the average number of SARS

\footnotetext{
${ }^{8}$ There is no clear evidence on the extent of underreporting of SARS cases. It is beyond the scope of this paper to determine how the population might respond to the need for medical help given potential negative consequences on their asset wealth during an epidemic.
} 
Bucchianeri: Is SARS a Poor Man's Disease?

cases per listing, excluding the four most severe sites. ${ }^{9}$ The estate-level SARS incidence rate is the ratio of the estimated number of SARS cases to the housing estate population.

The reader should be aware that there are several sources of error in my estimate. First, the SARS-list started on April 12, 2003, more than two weeks after the Amoy outbreak when community-level transmission of the disease was confirmed. Second, the variation in the number of cases per listing implies that my estimate is at best a crude measure of the relative severity of the outbreak in the listed buildings. Third, because the SARS-list was published to encourage stringent precautionary measures and self-monitoring of health conditions, especially for residents that might have contact with SARS patients, buildings were only kept on the SARS-list within ten days of hospitalization of the last SARS patient from that building. If there was more than a ten-day lag between the hospitalization of the patient and the diagnosis of SARS, the incubation period was considered to have passed, and the building in which the patient lived would not be put on the list. Therefore some buildings with SARS cases might have never appeared on the SARS-list.

To assess how accurate the estimation method I have adopted for creating the estate-level SARS incidence rate is, I repeat the same estimation process for all 18 districts, using a district instead of a housing estate as the unit of observation. Next, I compare the district-level estimates with the actual districtlevel SARS incidence rates provided by the Department of Health. The two measures have a correlation of 0.96 . The two measures are plotted against each other in Figure 3. ${ }^{10}$

\section{B. Measures of Socioeconomic Status and Other Resident Characteristics}

Hong Kong is divided into 18 Districts. District-level population density is calculated using population data from the 2001 Hong Kong Census and land area data from the National Bureau of Statistics of China.

Demographic and socioeconomic profiles of estate residents are proxied by Census 2001 data at the building-group level. Building groups (a total of 2,817 in Hong Kong, covering all 39,028 residential buildings) are divided according to building characteristics such as location, type, age and height (Fung, 2005). Population-weighted averages are taken for each estate across building groups to

\footnotetext{
9 According to the Health Department and supported by media reports, each non-SSE estate/building had a handful cases each time it was on the SARS list, due to the prodigious effort to quarantine any suspect cases promptly. There was no outlier.

${ }^{10}$ Both the estimated and the actual district-level SARS rates are derived using the Census 2001 population.
} 
which at least one building of the estate belongs. Tables $1 \mathrm{~A}$ and $1 \mathrm{~B}$ contain summary statistics.

\section{Pre-SARS Housing Sales and Rental Price Data}

To measure pre-SARS housing values, I have obtained access to transaction records of all sales and purchases of housing units in Hong Kong during the years 1993-1998 and 2001-2002. ${ }^{11}$

Housing estates are large-scale housing complexes consisting of many almost-identical blocks of housing units. The substantial similarity of units within each housing estate ensures that the average price level will be a reasonable reflection of housing values within that estate. Only estates with at least 2 transactions per month on average during the period 1993-1996 are included in my sample, for a more accurate measurement of price levels. A site of superspreading event (Amoy Gardens), suspected to have been struck by a particularly virulent strain, is excluded. Together, the 295 housing estates in my sample encompass more than 1.5 million people, about 23 percent of the Hong Kong population. They are situated in 17 of all 18 districts in Hong Kong, except for the Islands district that contains the outlying islands with a population of 86,667 (1.3 percent of territory total; Census 2001). There are 58 public housing estates in my sample; excluding the public estates does not change the results quantitatively or qualitatively.

Because of potential outliers, I use the median transaction prices as an indicator of housing values. ${ }^{12}$ Mean prices have a correlation in excess of 0.99 with the median prices in each year for the 295 estates in my sample. Using mean prices as an indicator of housing values produces very similar results. The housing price data is supplemented with data on monthly mortgage and rental payment from the 2001 Census.

\section{Estate Characteristics and Living Conditions}

I compiled data on the characteristics of the housing estates that might be related to the spread of SARS including: age, average flat size, availability of estate

\footnotetext{
${ }^{11}$ Data for years 1993-1998 are kindly shared by Tsur Sommerville. Purchase of data for years 2001-2002 was generously supported by a grant from the Andrew M. Mellon Foundation through the Research Program in Development Studies at Princeton University. Both data sets are based on Memorial Day Book of the Hong Kong Land Registry that records all sales and purchase instruments registered with the Registry, subject to the provisions of the Land Registration Ordinance.

${ }^{12}$ For example, it is not uncommon for housing units on the top two floors to be duplex units or penthouses. These units usually cost more than double most other housing units in that housing estate.
} 
facilities (such as health clubs, shopping arcades or childcare centers), number of floors, number of flats per floor, and number of blocks. ${ }^{13}$ I define the average space per person in each estate as the ratio of the estate-average flat size to the district-average of persons per housing unit derived from Census 2001. ${ }^{14}$

I measure the travel time to city center from a housing estate, defined as the amount of time spent on the most prevalent form of public transport to the closer of the two main commercial/ financial centers in Hong Kong, Tsim Sha Tsui and Central. Information on travel time to city center was collected from real estate agents and transportation companies.

Availability of health care facilities is checked on the website of Centaline Ltd., a leading property agent in Hong Kong. Under the map function, the numbers of three types of health care facilities can be searched within a northfacing $64 \mathrm{~m} \times 80 \mathrm{~m}\left(0.51 \mathrm{~km}^{2}\right)$ rectangle with each housing estate in the center: medical establishments (general hospitals and clinics, dental hospitals and a variety of health care facilities, both private and public), community doctor/ GP clinics and all other health-related facilities (such as pharmacies, dental clinics and Chinese medicine practitioners). Medical centers apparently unrelated to SARS, such as dental hospitals or optical care centers, are excluded from the medical establishment variable and added to the number of all other healthrelated facilities. Information on whether or not the housing estate is public is obtained from the Housing Authority.

\section{Empirical Findings}

As a first step, I estimate the following Tobit model:

$$
\mathrm{SARSP}_{\mathrm{i}}=\alpha+\gamma_{\mathrm{d}}+\varepsilon_{\mathrm{i}} \quad(\mathrm{i}=1, \ldots, 295)
$$

$\mathrm{SARSP}_{\mathrm{i}}$ refers to the SARS incidence rate of housing estate $i$ bounded between 0 and $1, \alpha$ is a constant term, $\gamma_{\mathrm{d}}$ a district fixed effect, and $\varepsilon_{\mathrm{i}}$ is a normally distributed error term with density function $\mathrm{N}\left(0, \sigma_{\mathrm{i}}\right)$. I weight the regression by the total number of flats in each estate to adjust for heteroskedasticity, assuming that $\sigma_{i}{ }^{2}$ is inversely proportional to the size of the housing estate. If we consider the estate-level SARS incidence rate to be the average of 1-0 outcomes (infected/ not infected) of all estate residents, then the variance of the error term will be of

\footnotetext{
${ }^{13}$ These data were compiled by research on the internet, phone calls to real estate agents and property developers, and visits to some of the estates. Age and the number of floors and flats per floor are averages across the housing estate; the number of blocks are often counted from site plans of the estates.

${ }^{14}$ There is not a lot of variation across districts. Mean [s.d.] of the number of households per quarter is 1.02 [0.03]; Mean [s.d.] of the number of persons per household is 3.16 [0.19].
} 
the form $\sigma^{2} / \mathrm{N}_{\mathrm{i}}$ where $\mathrm{N}_{\mathrm{i}}$ is the number of residents. In the Appendix, I present evidence that the model specification and the error assumption are appropriate.

District fixed effects are not significant as a group $(\mathrm{p}$-value $=0.25)$, nor is a district-level population density measure $(p$-value $=0.35)$. Because the lack of evidence towards a simple classification of districts into "high-risk type" and "low-risk type", the district-level variables are omitted from results presented. ${ }^{15}$ Furthermore, I do not find any strong support for a spatial correlation of the spread of SARS. Regression of the estate-level SARS incidence rate on the selfexcluding district-average incidence rate does not suggest a significant link, despite the upward bias due to feedback effects (Case, 1991; Manski, 2000). Therefore in the rest of the paper I focus on the SARS incidence rate of each housing estate as independent.

\section{A. Socioeconomic Status and SARS}

As discussed in Section 5, the SES variables are measured at the building-group level in three dimensions: income, education and occupation. Table 2 shows the regression results of the following Tobit model weighted by the total number of units:

$$
\operatorname{SARSP}_{\mathrm{i}}=\alpha+\beta \mathrm{SES}_{\mathrm{i}}+\varepsilon_{\mathrm{i}}
$$

Higher household income levels at either the upper quartile, median or lower quartile correlate with a lower SARS incidence rate (columns 1-3). Measures of personal income levels produce similar results. As the rest of the empirical results will show, the SES-SARS link found is the most stable along the dimension of income.

Column 4 shows the link between SARS and the share of working population in different occupations. The SARS incidence increases most significantly with the share of workers employed in service industries/ shops and secondly for professionals, against a baseline category of elementary, agricultural and fishery and other unclassified workers. The share of managers, administrators and craft workers in the workforce does not correlate significantly with the SARS incidence rate. Likely explanations include the workers' high contact rate with the general population (and thus SARS cases) and the proximity of shops and other places where the public convene and the disease spreads. Part of the link between SARS incidence and the share of the workforce who are (associate) professionals

\footnotetext{
${ }^{15}$ For robustness checks, district dummies (or district-level population density) are added to all regressions presented in this paper but neither control ever has statistical significance at 10\%. The main results remain qualitatively similar in all cases and quantitatively in most cases. The withindistrict correlations are not as robust as the across-district correlations.
} 
Bucchianeri: Is SARS a Poor Man’s Disease?

can be due to the inclusion of healthcare workers and other client-based professionals (such as consultants) in the category. Similar results are found in column 5 using two broad occupation groups. This suggests a more complex relationship between occupations and SARS other than a simplistic characterization confined to medical professionals.

Notably, the effect of income on the spread of SARS is independent of occupation. This result is consistent with findings in the literature. As early as 1872, Friedrich Engels (1872) argued that lower income areas where "workers are crowded together are the breeding places of all those epidemics." Income can affect SARS incidence through one of the following channels: consumption, psychobiological impact, and exit. Higher purchasing power or permanent income positively relates to expenditures on goods that might contribute to the functioning of the immune system or general health status (e.g., living conditions, healthcare and nutrition). ${ }^{16}$ Further, there is evidence that socioeconomic circumstances have biological effects on immune functions (Brunner, 1997). Higher-income households presumably also found it easier to leave Hong Kong when the epidemic struck.

One hypothesis that supports an SES-SARS link is that the more educated adopt appropriate health habits more efficiently. Columns 6 and 7 show no significant relationship between SARS incidence and the education level, despite the high correlation (0.7-0.8) between the education attainment measures and median household income level. ${ }^{17}$ This discounts the differential health behavior story, consistent with findings in Lau et al. (2003), where the general population adopted behavioral changes in response to an epidemic threat independent of educational attainment. It is also suggestive of a different dynamic for infectious diseases where susceptibility relies heavily on preventive measure adoption (Gregson et al., 2001; Tang and Wong, 2003).

Marmot (2002) argues that full participation in society might be as important as the purchasing power derived from income. Columns 8 and 9 in Table 2 do not offer much support that this mechanism was at work in the case of SARS. The last two columns in Table 2 demonstrate the income-SARS link and the occupation-SARS link are more or less independent.

\footnotetext{
${ }^{16}$ Environmental factors have been proved to be important at least in one super-spreading event. (Hong Kong Department of Health, 2003; WHO, 2003) Household overcrowding and lower population density in less expensive, more remote residential areas both impact the transmission of SARS, but in opposite directions.

${ }^{17}$ Since education does not correlate significantly with the spread of SARS without other controls, results where education remains insignificant when other factors (e.g., income and occupations) are controlled for are not shown.
} 


\section{B. Possible Channels of the Income-SARS Link}

Housing service consumption is expected to increase with current income level, permanent income and the quality of housing services (which can in turn reflect preferences related or unrelated with SES). To explore the income-SARS correlation identified in the previous section I regress:

$$
\mathrm{SARSP}_{\mathrm{i}}=\alpha+\text { Income }_{\mathrm{i}} \beta+\mathbf{H}_{\mathrm{i}} \gamma+\varepsilon_{\mathrm{i}}
$$

where $\mathrm{H}_{\mathrm{i}}$ is a measure of value of housing service consumption of the households and other variables defined as before. Four separate indicators are used: building group-level monthly rental price; estate-level average sales price in years 199598, 2001-2002; estate-level average sales price in year 2002; and building grouplevel monthly mortgage payment. While rental price can be expected to best reflect the user cost of housing without influence of price expectations and other macroeconomic factors, it is derived from Census 2001 at the building-group level only. No data closer to the 2003 epidemic or at a more disaggregate level is available. Mortgage payment is likely to have the least accurate indicator out of the four, being both measured by the building group level and affected by factors such as when the mortgage was taken out and structure of the mortgage. Nevertheless, Table 3 demonstrates that different housing service value indicators produce results that point in the same direction. The main conclusion from this analysis is that the income-SARS link is much reduced in both size and statistical significance when housing service value is controlled for, while the occupationSARS link remains robust.

To put the main coefficients in context, two standard deviations' increase in the median income (approximately \$900) is associated with a reduction of 1 to 1.5 SARS case per 100,000 . An alternative way of describing this SES-SARS relationship is that one standard deviation's increase (approximately $\$ 180$ ) in the median monthly rent is associated with a reduction of 1 case per 100,000. Estimates related to occupations span a wider range, depending on the regression specification; one percent increase in the employment share of high-contact occupations (about an 8\% increase in percentage points) is related to an increase of 100-200 cases per 100,000. While interpreting these numbers, readers should be mindful that income, housing consumption and occupations are interrelated. As will be shown further in Section $6 \mathrm{C}$ below, it is more useful to think of these results as a group, rather than independent correlations. 
Bucchianeri: Is SARS a Poor Man’s Disease?

\section{Measurable Living Conditions}

One can think of the rental or sales price of a housing unit as the market value of a vector of living amenities and neighborhood qualities, some of them (such as social capital) unobservable. This section explores numerous measurable aspects of living patterns and conditions $(\boldsymbol{L})$ that might have been proxied by housing service value:

$$
\text { SARSP }_{i}=\alpha+\text { Income }_{i} \beta+\mathbf{L}_{i} \tau+\varepsilon_{i} .
$$

Notably, Table 4 shows that while some living condition indicators have a significant correlation with SARS incidence, the income-SARS link remains robust. Also, comparing column 1 with the rest of the table, neither the magnitude of the income-SARS link nor that of the occupation-SARS link experiences any noticeable reduction. Results using the other 3 income level indicators are similar and available upon request.

The proportion of students and workers who use public transportation relates a higher SARS incidence rate (column 2). It might be due to a higher contact rate with the public and also sharing of facilities by the users of public transportation. This finding is also consistent with WHO (2003) which recommends special consideration to be given to confined spaces including aircrafts and vehicles. The coefficient on income level adjusts slightly downwards, suggesting that at least part of the income-SARS link is related to the usage of public transportation. A higher incidence rate in estates with facilities such as health clubs and childcare centers (column 3) might either be due to a higher usage rate during the epidemic (as compared to residents in other estates who stopped using similar facilities outside their estates because of the general wariness of transportation) or a lower level of environmental hygiene. The number of floors per building correlates with the sharing of elevators with a sawtooth pattern. As column 4 shows, it is significant at $10 \% .{ }^{18}$ These are the risk factors that demonstrate a consistent relationship with SARS incidence using different income measures.

On the other hand, the proximity to health-related establishments (public and private hospitals, general practitioner clinics and pharmacies) does not correlate with the spread of SARS. Anecdotal evidence shows that the general public tended to avoid health facilities during the epidemic; this behavioral change might have resulted in the absence of a health facility-SARS link.

\footnotetext{
${ }^{18}$ If, say, there is an additional elevator bank for every 15 floors, elevator-sharing increases with the number of floors up to 15 floors, but the amount of elevator-sharing in a 16-story building is only as much as that in an 8-story building, and it keeps increasing until the number of floors reaches 30 .
} 
Similarly, three indicators that potentially capture population and living density travel time to city centers, space per person in the average unit and the average number of units per floor - do not have a strong relationship with SARS incidence (columns 5-8). ${ }^{19}$ The average age of buildings within the estate generally relates to more depreciation of less modern facilities, but no significant impact is found (column 9). Column 10 shows that any difference in building management and the level of general building maintenance between private and public estates does not create a gap between the two types of estates in terms of SARS incidence. ${ }^{20}$

\section{Testing Other Related Hypotheses}

This section examines whether the homeownership rate and income inequality at the building group level affect SARS incidence. There is evidence in the literature that homeowners have more incentives to invest in local amenities and social capital due to low mobility (e.g., DiPasquale and Glaeser, 1999). Because environmental contamination is a risk factor for SARS and there are clear externalities of maintaining a hygienic environment during the epidemic, it is interesting to explore the role of homeownership in this setting. An editorial in the British Medical Journal (1996) proposes an important role of income distribution in determining health outcomes, while Waldmann (1992) draws a link between income inequality and infant mortality. Because the disease in concern is an acute condition that might affect people with lower baseline health status, an income inequality-SARS link will be of second-order.

I explore the impact of homeownership and income inequality on the SARS incidence rate, controlling for the income level, share of workers in highcontact occupations and living conditions that are significant in the previous section. Columns 2-4 of Table 5 show the results; column 1 is for comparison. Homeownership correlates with SARS incidence only at 15\% significance. Experimenting with different functional forms or restricting the sample to private estates leads to similar results. There is no strong evidence that homeownership is an important determinant. Similarly, any effect of income inequality is not apparent in the data.

\footnotetext{
${ }^{19}$ Travel time is significant at $10 \%$ but this result is not robust using other income indicators.

${ }^{20}$ One potential bias is that many public housing estates are rental only, and they are excluded from my sample because I do not observe any open market transactions for them. While half of the Hong Kong population live in public housing estates, only about a quarter of my sample are public (Table 1B).
}

DOI: $10.2202 / 1558-9544.1209$ 
Bucchianeri: Is SARS a Poor Man's Disease?

\section{Discussion}

This paper investigates the association between socioeconomic status and the spread of a communicable disease, SARS. This complements the wider literature of a SES-health relationship in a more universal setting. Understanding SARS incidence is important for devising epidemic control strategies and public health policies. Given that SARS is unlikely to be the last of the emerging diseases posing a global epidemic threat, it is worth considering what lessons we can learn from the 2003 SARS epidemic. ${ }^{21}$

A significant and negative association between SARS incidence and income is identified, after controlling for the share of population in high-contact occupations. The nature of the identified SES-SARS link is likely to be largely causal. Because SARS is a new and unanticipated disease, it cannot have directly led to sorting among the population into housing estates according to their susceptibility to SARS. The prodigious level of public health efforts to combat SARS makes differences in access to suitable health care an unlikely explanation. Moreover, widespread adoption of precautionary practices implies that differential adoption of health habits is likely to be small.

Living conditions potentially form an important channel of the incomeSARS link. Housing complexes with higher usage of public transportation, communal facilities and a higher number of floors (possibly related to elevatorsharing) experienced a higher SARS incidence rate. These results all point to higher contact rates and sharing of facilities, although future research with more detailed information about property details and population behaviors is needed to ascertain the nature of these relationships. Interestingly, proximity to healthrelated establishments does not relate to the SARS incidence, which might be a result of behavioral changes of the population that can mitigate the spread of SARS. Household crowding, distance from city centers and the average age of the buildings do not show correlations with SARS, neither do homeownership rate or income inequality. Notably, while the income-SARS link is accounted for using housing consumption indicators, it remains robust with an array of living condition measures. This suggests that permanent income plays a role.

Education does not seem to have affected susceptibility to SARS; this resonates with evidence for the adoption of preventive measures by perceived susceptibility instead of education (Tang and Wong, 2003). Findings in Lau et al. (2003) suggest that the rate of adaptation of behavioral changes in relation to education attainment and professional knowledge might be counter-intuitive. It raises questions about the role of education in the control of other infectious diseases where health behavior adoption is important. Especially given the strong

${ }^{21}$ SARS: A Pandemic Prevented. Science, Dec 2003. 
correlation between income and education, it is important to understand the exact channels through which various SES measures relate to the spread of a disease.

While much is still unknown about SARS, this paper contributes to our understanding of the spread of SARS. It also provides new evidence on the SEShealth link in the setting of a low-risk but high-cost event involving a new disease with epidemic potentials. Future research is needed to determine the exact nature of the relationships between the spread of SARS and various factors, including occupation, sharing of facilities and choice of transportation. None of the government measures used to combat SARS during and in the aftermath of the 2003 epidemic was devised with a link between SARS and economic conditions in mind. ${ }^{22}$ Given the findings in this paper, it is worth taking the SES-SARS gradient into account when formulating the optimal strategy of surveillance and control of related diseases.

22 "Checklist of Measures to Combat SARS". Hong Kong Government website.

DOI: $10.2202 / 1558-9544.1209$ 


\section{Bucchianeri: Is SARS a Poor Man's Disease?}

\section{Table 1A: Summary Statistics -- District Characteristics}

\begin{tabular}{|c|c|c|c|c|c|c|c|c|c|c|c|c|}
\hline $\begin{array}{l}\text { District } \\
\text { No. }\end{array}$ & District Name & $\begin{array}{l}\text { District } \\
\text { Population } \\
\text { ('000) }\end{array}$ & $\begin{array}{l}\text { SARS } \\
\text { Incidence } \\
\text { Rate (per } \\
100,000 \text { ) }\end{array}$ & $\begin{array}{l}\text { Median Monthly } \\
\text { Income from Main } \\
\text { Occupation (USD) }\end{array}$ & $\begin{array}{c}\text { Median } \\
\text { Monthly } \\
\text { Household } \\
\text { Income (USD) }\end{array}$ & $\begin{array}{l}\text { \% of Tertiary } \\
\text { Educated, Aged } \\
20+\text { Non- } \\
\text { students }\end{array}$ & $\begin{array}{l}\text { Labor Force } \\
\text { Participation } \\
\text { Rate }(\%)\end{array}$ & $\begin{array}{l}\text { Male Labor } \\
\text { Force } \\
\text { Participation } \\
(\%)\end{array}$ & $\begin{array}{c}\text { Female Labor } \\
\text { Force } \\
\text { Participation } \\
(\%)\end{array}$ & $\begin{array}{l}\% \text { of Households } \\
\text { Owning Quarters } \\
\text { Occupied }\end{array}$ & $\begin{array}{l}\text { Median Monthly } \\
\text { Household } \\
\text { Mortgage/ Loan } \\
\text { Payment (USD) }\end{array}$ & $\begin{array}{l}\text { Median Monthly } \\
\text { Household Rent } \\
\text { (USD) }\end{array}$ \\
\hline 1 & $\begin{array}{r}\text { Central \& } \\
\text { Western }\end{array}$ & 261.88 & 4.69 & 1677 & 3271 & 31.0 & 66.7 & 75.0 & 59.6 & 60.0 & 1484 & 800 \\
\hline 2 & Wan Chai & 167.15 & 9.45 & 1677 & 3355 & 34.1 & 65.9 & 74.0 & 59.5 & 56.6 & 1935 & 968 \\
\hline 3 & Eastern & 616.20 & 12.25 & 1548 & 3059 & 21.7 & 62.7 & 72.4 & 54.1 & 61.5 & 1290 & 258 \\
\hline 4 & Southern & 290.24 & 4.84 & 1355 & 2994 & 18.8 & 62.1 & 70.1 & 54.8 & 41.4 & 1342 & 185 \\
\hline 6 & Sham Shui Po & 353.55 & 16.88 & 1290 & 1806 & 13.3 & 56.8 & 67.1 & 46.9 & 38.4 & 1226 & 192 \\
\hline 7 & Kowloon City & 381.35 & 17.49 & 1355 & 2555 & 20.6 & 60.2 & 69.4 & 52.2 & 55.4 & 1445 & 281 \\
\hline 8 & Wong Tai Sin & 444.63 & 19.74 & 1290 & 2077 & 9.6 & 57.0 & 68.3 & 46.0 & 36.8 & 968 & 194 \\
\hline 9 & Kwun Tong & 562.43 & 96.11 & 1290 & 2032 & 12.1 & 58.0 & 68.4 & 47.8 & 38.1 & 1110 & 171 \\
\hline 13 & Yuen Long & 449.07 & 12.90 & 1290 & 2065 & 11.6 & 61.6 & 74.7 & 49.1 & 52.1 & 994 & 160 \\
\hline 14 & North & 298.66 & 21.15 & 1290 & 2220 & 10.7 & 60.2 & 73.1 & 47.9 & 57.5 & 903 & 168 \\
\hline 15 & Tai Po & 310.88 & 64.36 & 1290 & 2387 & 13.6 & 61.7 & 73.7 & 50.5 & 61.1 & 895 & 168 \\
\hline 16 & Sha Tin & 628.63 & 42.99 & 1419 & 2700 & 16.5 & 62.5 & 73.4 & 52.4 & 56.3 & 1092 & 191 \\
\hline 17 & Sai Kung & 327.69 & 19.82 & 1419 & 2710 & 16.1 & 65.2 & 75.3 & 55.7 & 58.5 & 1123 & 207 \\
\hline \multicolumn{13}{|c|}{ Total: 6615.827} \\
\hline \multirow{2}{*}{\multicolumn{3}{|c|}{$\begin{array}{l}\text { Weighted Mean } \\
\text { Weighted S.d. }\end{array}$}} & 26.45 & 1370.04 & 2441.18 & 15.74 & 61.38 & 71.96 & 51.41 & 50.66 & 1156.20 & 246.19 \\
\hline & & & 26.01 & 117.93 & 449.98 & 5.96 & 2.68 & 2.72 & 3.62 & 10.00 & 228.83 & 177.97 \\
\hline \multicolumn{3}{|c|}{$\begin{array}{l}\text { Weighted correlation with SARS } \\
\text { Incidence rate }\end{array}$} & -- & -0.30 & -0.30 & -0.29 & -0.32 & -0.31 & -0.38 & -0.25 & -0.27 & -0.27 \\
\hline
\end{tabular}

Note: No housing estate in the sample is located in Islands District (\#18), which is consequently omitted from the table. Mean and standard deviation are weighted by district population. Source: Hong Kong Census 2000 , Hong Kong Department of Health
SRS 
Forum for Health Economics \& Policy, Vol. 13 [2010], Iss. 2, Art. 10

Table 1B: Summary Statistics -- Housing Estate Characteristics

Weighted Mean ${ }^{1}$ (s.d./ s.e.)

\begin{tabular}{|c|c|c|c|c|}
\hline \multicolumn{5}{|c|}{ Weighted Mean ${ }^{1}$ (s.d./ s.e.) } \\
\hline & $\begin{array}{c}\text { (1) } \\
\text { All } 295 \text { Estates }\end{array}$ & $\begin{array}{c}(2) \\
\text { 66 SARS-affected } \\
\text { Estates }\end{array}$ & $\begin{array}{l}(3) \\
229 \text { Unaffected } \\
\text { Estates }\end{array}$ & $\begin{array}{c}(4) \\
\text { Difference } \\
{ }^{3}(2)-(3)\end{array}$ \\
\hline \multicolumn{5}{|l|}{ SARS Incidence } \\
\hline Estimated no. of SARS cases per 100,000 residents & $\begin{array}{c}17.20 \\
(31.46)\end{array}$ & $\begin{array}{c}41.38 \\
(37.34)\end{array}$ & -- & -- \\
\hline No. of Times Appearing on SARS-list & $\begin{array}{c}0.88 \\
(1.62)\end{array}$ & $\begin{array}{c}2.12 \\
(1.92)\end{array}$ & -- & -- \\
\hline No. of Days Spent on SARS-list & $\begin{array}{c}4.10 \\
(6.60)\end{array}$ & $\begin{array}{c}9.87 \\
(6.95)\end{array}$ & -- & -- \\
\hline \multicolumn{5}{|l|}{ Pre-SARS Sales Price } \\
\hline Median Sales Price per Sq. Ft., 2002 (USD) & $\begin{array}{c}266.10 \\
(220.01)\end{array}$ & $\begin{array}{c}245.02 \\
(134.33)\end{array}$ & $\begin{array}{c}283.10 \\
(266.23)\end{array}$ & $\begin{array}{c}-38.08 \\
{[26.71]}\end{array}$ \\
\hline Average Median Sales Price per Sq. Ft., 1995-98, 2001-02 & $\begin{array}{c}423.26 \\
(327.12)\end{array}$ & $\begin{array}{c}377.57 \\
(173.15)\end{array}$ & $\begin{array}{c}460.18 \\
(404.13)\end{array}$ & $\begin{array}{l}-82.61 * \\
{[42.72]}\end{array}$ \\
\hline \multicolumn{5}{|l|}{ Estate Characteristics } \\
\hline Minimum Travel Time to City Centre (Hours) & $\begin{array}{c}0.53 \\
(0.25)\end{array}$ & $\begin{array}{c}0.56 \\
(0.23)\end{array}$ & $\begin{array}{c}0.51 \\
(0.27)\end{array}$ & $\begin{array}{l}0.05^{*} \\
{[0.03]}\end{array}$ \\
\hline Average Flat Size (Square Foot) & $\begin{array}{c}715.11 \\
(255.99)\end{array}$ & $\begin{array}{c}728.15 \\
(213.05)\end{array}$ & $\begin{array}{c}705.84 \\
(283.04)\end{array}$ & $\begin{array}{c}15.81 \\
{[30.15]}\end{array}$ \\
\hline Building Age & $\begin{array}{l}16.74 \\
(6.57)\end{array}$ & $\begin{array}{l}17.41 \\
(7.73)\end{array}$ & $\begin{array}{l}16.26 \\
(5.61)\end{array}$ & $\begin{array}{l}1.29 * \\
{[0.77]}\end{array}$ \\
\hline No. of Floors per Block & $\begin{array}{l}28.53 \\
(7.94)\end{array}$ & $\begin{array}{l}28.62 \\
(7.62)\end{array}$ & $\begin{array}{l}28.47 \\
(8.19)\end{array}$ & $\begin{array}{c}0.33 \\
{[0.93]}\end{array}$ \\
\hline No. of Flats per Floor & $\begin{array}{c}8.52 \\
(2.98)\end{array}$ & $\begin{array}{c}8.65 \\
(2.98)\end{array}$ & $\begin{array}{c}8.42 \\
(2.99)\end{array}$ & $\begin{array}{c}0.21 \\
{[0.35]}\end{array}$ \\
\hline Availability of Estate Facilities (1-0 Dummy) & $\begin{array}{c}0.68 \\
(0.47)\end{array}$ & $\begin{array}{c}0.86 \\
(0.35)\end{array}$ & $\begin{array}{c}0.55 \\
(0.50)\end{array}$ & $\begin{array}{c}0.32 * * * \\
{[0.05]}\end{array}$ \\
\hline Public Housing Dummy & $\begin{array}{c}0.24 \\
(0.43)\end{array}$ & $\begin{array}{c}0.18 \\
(0.39)\end{array}$ & $\begin{array}{c}0.28 \\
(0.45)\end{array}$ & $\begin{array}{c}-0.11 * * \\
{[0.05]}\end{array}$ \\
\hline $\begin{array}{l}\text { Close-by Healthcare Facilities } \\
\text { (within } 0.51 \mathrm{sq} \mathrm{km} \text { Area) }\end{array}$ & & & & \\
\hline Medical Establishments Dummy & $\begin{array}{c}0.63 \\
(0.48)\end{array}$ & $\begin{array}{c}0.69 \\
(0.47)\end{array}$ & $\begin{array}{c}0.59 \\
(0.49)\end{array}$ & $\begin{array}{l}0.10^{*} \\
{[0.06]}\end{array}$ \\
\hline General Practitioners Dummy & $\begin{array}{c}0.15 \\
(0.36)\end{array}$ & $\begin{array}{c}0.18 \\
(0.39)\end{array}$ & $\begin{array}{c}0.12 \\
(0.33)\end{array}$ & $\begin{array}{c}0.06 \\
{[0.04]}\end{array}$ \\
\hline Other Health-Related Facilities Dummy & $\begin{array}{c}0.10 \\
(0.31)\end{array}$ & $\begin{array}{c}0.08 \\
(0.27)\end{array}$ & $\begin{array}{c}0.12 \\
(0.33)\end{array}$ & $\begin{array}{c}-0.05 \\
{[0.04]}\end{array}$ \\
\hline
\end{tabular}

${ }^{1}$ All measures are weighted by total no. of flats in each housing estate. Standard deviations reported in parentheses. Standard errors reported in brackets in the 4 th column; ${ }^{* * *}$ denotes significance at $1 \%, * * 5 \%$ and $* 10 \%$.

${ }^{2}$ An Estate was Sars-affected if it ever appeared on the Department of Health "List of Buildings with Confirmed Cases". The housing estates are largescale housing complexes, located in 17 of all 18 districts of Hong Kong.

${ }^{3}$ Differences in characteristics by whether SARS affected the estate or not amounts to regressing the characteristics on a 1-0 SARS incidence dummy.

${ }^{4}$ Medical Establishments include hospitals, clinics and health care centres. General Practitioners are the community doctors in Hong Kong. Other

Health-Related Facilities include pharmacies, dental hospitals or Chinese medicine practitioners.

DOI: 10.2202/1558-9544.1209 
Bucchianeri: Is SARS a Poor Man's Disease?

Table 2: Socioeconomic Status (SES) and SARS Incidence

\begin{tabular}{|c|c|c|c|c|c|c|c|c|c|c|c|}
\hline & (1) & (2) & (3) & $\begin{array}{l}\text { Depenc } \\
(4)\end{array}$ & $\begin{array}{c}\text { ent Variable } \\
(5)\end{array}$ & $\begin{array}{l}\text { SARS Incid } \\
(6) \\
\end{array}$ & $\begin{array}{l}\text { ice Rate per } \\
\text { (7) }\end{array}$ & $\begin{array}{r}100,000 \\
(8) \\
\end{array}$ & (9) & $(10)$ & $(10)$ \\
\hline $\begin{array}{l}\text { Monthly domestic household income } \\
\text { for the median }\end{array}$ & $\begin{array}{c}-1.012 * * \\
(0.429)\end{array}$ & -- & -- & -- & -- & -- & -- & -- & -- & $\begin{array}{l}-0.912 \\
(1.246)\end{array}$ & $\begin{array}{c}-1.696 * * * \\
(0.530)\end{array}$ \\
\hline $\begin{array}{l}\text { Monthly domestic household income } \\
\text { for the lower quartile }\end{array}$ & -- & $\begin{array}{c}-1.540 * * \\
(0.713)\end{array}$ & -- & -- & -- & -- & -- & -- & -- & -- & -- \\
\hline $\begin{array}{l}\text { Monthly domestic household income for } \\
\text { the upper quartile }\end{array}$ & -- & -- & $\begin{array}{c}-0.649 * * \\
(0.259)\end{array}$ & -- & -- & -- & -- & -- & -- & -- & -- \\
\hline $\begin{array}{l}\text { Log } \% \text { of working pop who are clerks, service } \\
\text { workers and shop sales workers }\end{array}$ & -- & -- & -- & $\begin{array}{c}91.086^{* * *} \\
(30.214)\end{array}$ & -- & -- & -- & -- & -- & $\begin{array}{c}69.958 \\
(41.023)\end{array}$ & -- \\
\hline $\begin{array}{l}\log \% \text { of working pop who are (associate) } \\
\text { professionals }\end{array}$ & -- & -- & -- & $\begin{array}{l}62.074^{*} \\
(32.158)\end{array}$ & -- & -- & -- & -- & -- & $\begin{array}{c}60.952 \\
(32.262)\end{array}$ & -- \\
\hline $\begin{array}{l}\text { Log } \% \text { of working pop who are managers/ } \\
\text { administrators }\end{array}$ & -- & -- & -- & $\begin{array}{c}37.151 \\
(24.868)\end{array}$ & -- & -- & -- & -- & -- & $\begin{array}{c}37.658 \\
(24.933)\end{array}$ & -- \\
\hline $\begin{array}{l}\text { Log } \% \text { of working pop who are craft workers } \\
\text { and machine operators }\end{array}$ & -- & -- & -- & $\begin{array}{c}-1.819 \\
(21.651)\end{array}$ & -- & -- & -- & -- & -- & $\begin{array}{l}-6.555 \\
(22.673)\end{array}$ & -- \\
\hline $\begin{array}{l}\log \% \text { of working pop in high-contact }{ }^{\dagger} \\
\text { occupations }\end{array}$ & -- & -- & -- & -- & $\begin{array}{l}109.546^{*} \\
(59.874)\end{array}$ & -- & -- & -- & -- & -- & $\begin{array}{r}206.155^{* * *} \\
(68.845)\end{array}$ \\
\hline $\begin{array}{l}\text { Log } \% \text { of pop with primary-school education } \\
\text { or less }\end{array}$ & -- & -- & -- & -- & -- & $\begin{array}{c}10.123 \\
(14.978)\end{array}$ & -- & -- & -- & -- & -- \\
\hline $\begin{array}{l}\text { Log } \% \text { of pop with high-school education } \\
\text { or less }\end{array}$ & -- & -- & -- & -- & -- & -- & $\begin{array}{c}35.751 \\
(35.800)\end{array}$ & -- & -- & -- & -- \\
\hline $\log \%$ of pop who are employed & -- & -- & -- & -- & -- & -- & -- & $\begin{array}{c}-50.04 \\
(37.384)\end{array}$ & -- & -- & -- \\
\hline $\begin{array}{l}\text { Log } \% \text { of pop who are not working, retired or } \\
\text { in full-time studies }\end{array}$ & -- & -- & -- & -- & -- & -- & -- & -- & $\begin{array}{l}-3.833 \\
(8.254)\end{array}$ & -- & -- \\
\hline No. of observations & 294 & 294 & 294 & 294 & 294 & 294 & 294 & 295 & 291 & 294 & 294 \\
\hline
\end{tabular}

1 Standard errors in parentheses

$2 *$ significant at $10 \% ; * *$ significant at $5 \% ; * * *$ significant at $1 \%$

† High-contact occupations include Service Workers \& Shop Sales Workers, Managers \& Administrators and (Associate) Professionals. Please see text for more details. 


\section{Table 3: Housing Service Consumption and SARS Incidence}

\begin{tabular}{|c|c|c|c|c|}
\hline \multirow{3}{*}{ Monthly domestic household income for the median } & \multicolumn{4}{|c|}{ Dependent Variable: SARS Incidence Rate per 100,000} \\
\hline & $(1)$ & $(2)$ & (3) & $(4)$ \\
\hline & $\begin{array}{l}-0.689 \\
(0.609)\end{array}$ & $\begin{array}{c}0.410 \\
(1.395)\end{array}$ & $\begin{array}{l}-0.699 \\
(1.067)\end{array}$ & $\begin{array}{l}-1.36^{* *} \\
(0.589)\end{array}$ \\
\hline Log $\%$ of working pop in high-contact ${ }^{\dagger}$ occupations & $\begin{array}{c}233.916^{* * *} \\
(69.964)\end{array}$ & $\begin{array}{c}244.171^{* * *} \\
(89.067)\end{array}$ & $\begin{array}{c}191.297^{* * *} \\
(72.468)\end{array}$ & $\begin{array}{c}259.425^{* * * *} \\
(83.518)\end{array}$ \\
\hline Median monthly household rent for renting domestic households & $\begin{array}{c}-5.631 * * * \\
(2.063)\end{array}$ & -- & -- & -- \\
\hline Average median transaction price (per sq. ft.) in 1995-98, 2001-02 & -- & $\begin{array}{l}-1.782 \\
(1.124)\end{array}$ & -- & -- \\
\hline Median transaction price (per sq. ft.) in 2002 & -- & -- & $\begin{array}{l}-1.149 \\
(1.084)\end{array}$ & -- \\
\hline Median monthly mortgage payment for households with mortgage & -- & -- & -- & $\begin{array}{l}-2.169 \\
(1.769)\end{array}$ \\
\hline No. of observations & 292 & 239 & 279 & 294 \\
\hline
\end{tabular}

1 Standard errors in parentheses

$2 *$ significant at $10 \% ; *$ significant at $5 \% ; * * *$ significant at $1 \%$

† High-contact occupations include Service Workers \& Shop Sales Workers, Managers \& Administrators and (Associate)

Professionals. Please see text for more details. 
Bucchianeri: Is SARS a Poor Man's Disease?

Table 4: Income, Living Conditions and SARS Incidence

\begin{tabular}{|c|c|c|c|c|c|c|c|c|c|c|}
\hline & $(1)$ & (2) & (3) & $\begin{array}{c}\text { Dependent V } \\
\text { (4) }\end{array}$ & $\begin{array}{l}\text { ariable: SARS } \\
\text { (5) }\end{array}$ & $\begin{array}{l}\text { Incidence Rat } \\
\text { (6) }\end{array}$ & $\begin{array}{l}\text { eper } 100,000 \\
\quad(7)\end{array}$ & $(8)$ & (9) & $(10)$ \\
\hline $\begin{array}{l}\text { Monthly domestic household } \\
\text { income for the median }\end{array}$ & $\begin{array}{c}-1.696^{* * *} \\
(0.530)\end{array}$ & $\begin{array}{c}-1.432 * * * \\
(0.543)\end{array}$ & $\begin{array}{c}-1.750 * * * \\
(0.550)\end{array}$ & $\begin{array}{c}-1.633 * * * \\
(0.522)\end{array}$ & $\begin{array}{c}-1.682 * * * \\
(0.539)\end{array}$ & $\begin{array}{c}-2.309 * * * \\
(0.761)\end{array}$ & $\begin{array}{c}-1.461 * * * \\
(0.527)\end{array}$ & $\begin{array}{c}-1.514 * * * \\
(0.550)\end{array}$ & $\begin{array}{c}-1.701 * * * \\
(0.534)\end{array}$ & $\begin{array}{c}-1.705^{* * *} \\
(0.541)\end{array}$ \\
\hline $\begin{array}{l}\log \% \text { of working pop in } \\
\text { high-contact广 occupations }\end{array}$ & $\begin{array}{c}206.155^{* * *} \\
(68.845)\end{array}$ & $\begin{array}{c}166.033^{* *} \\
(70.985)\end{array}$ & $\begin{array}{l}113.049^{*} \\
(68.248)\end{array}$ & $\begin{array}{l}211.326^{* * *} \\
(68.203)\end{array}$ & $\begin{array}{c}209.611^{* * *} \\
(70.644)\end{array}$ & $\begin{array}{l}224.065^{* * *} \\
(71.352)\end{array}$ & $\begin{array}{c}215.961^{* * *} \\
(68.346)\end{array}$ & $\begin{array}{l}222.270^{* * *} \\
(71.185)\end{array}$ & $\begin{array}{l}206.526 * * * \\
(68.985)\end{array}$ & $\begin{array}{c}202.792^{* *} \\
(78.221)\end{array}$ \\
\hline $\begin{array}{l}\log \% \text { of students \& workers who } \\
\text { take public transportation }\end{array}$ & -- & $\begin{array}{l}71.771^{*} \\
(39.740)\end{array}$ & -- & -- & -- & -- & -- & -- & -- & -- \\
\hline $\begin{array}{l}=1 \text { if estate facilities (e.g., health } \\
\text { club) are available }\end{array}$ & -- & -- & $\begin{array}{c}87.191 * * * \\
(18.093)\end{array}$ & -- & -- & -- & -- & -- & -- & -- \\
\hline Average no. of floors per building & -- & -- & -- & $\begin{array}{l}1.536^{*} \\
(0.814)\end{array}$ & -- & -- & -- & -- & -- & -- \\
\hline $\begin{aligned}= & 1 \text { if medical establishments are } \\
& \text { closeby } \Phi\end{aligned}$ & -- & -- & -- & -- & $\begin{array}{c}17.767 \\
(13.724)\end{array}$ & -- & -- & -- & -- & -- \\
\hline $\begin{aligned}= & 1 \text { if community doctors are } \\
& \text { closeby } \Phi\end{aligned}$ & -- & -- & -- & -- & $\begin{array}{c}12.019 \\
(20.298)\end{array}$ & -- & -- & -- & -- & -- \\
\hline $\begin{array}{l}=1 \text { if other health-related facilities } \\
\text { are closeby } \Phi\end{array}$ & -- & -- & -- & -- & $\begin{array}{l}-15.76 \\
(25.862)\end{array}$ & -- & -- & -- & -- & -- \\
\hline $\begin{array}{l}\text { Average space per household } \\
\text { member, sq. ft. }\end{array}$ & -- & -- & -- & -- & -- & $\begin{array}{c}0.148 \\
(0.125)\end{array}$ & -- & -- & -- & -- \\
\hline $\begin{array}{l}\text { Minimum travel time to city } \\
\text { centers, hours }\end{array}$ & -- & -- & -- & -- & -- & -- & $\begin{array}{l}45.788 \\
(26.516)\end{array}$ & -- & -- & -- \\
\hline Average no. of units per floor & -- & -- & -- & -- & -- & -- & -- & $\begin{array}{c}2.904 \\
(2.391)\end{array}$ & -- & -- \\
\hline Average age of buildings & -- & -- & -- & -- & -- & -- & -- & -- & $\begin{array}{l}-0.079 \\
(0.915)\end{array}$ & -- \\
\hline$=1$ if estate is public & -- & -- & -- & -- & -- & -- & -- & -- & -- & $\begin{array}{c}-1.717 \\
(19.089)\end{array}$ \\
\hline No. of observations & 294 & 294 & 294 & 294 & 294 & 294 & 294 & 294 & 294 & 294 \\
\hline
\end{tabular}

1 Standard errors in parentheses
$2 *$ significant at $10 \%$; * significant at $5 \%$; ** significant at $1 \%$

† High-contact occupations include Service Workers \& Shop Sales Workers, Managers \& Administrators and (Associate) Professionals. Please see text for more details.

$\Phi$ “Closeby" establishments refer to those within approximately $0.5 \mathrm{sq}$. km. Please see text for more details. 
Table 5: Homeownership, Income Inequality and SARS Incidence

\begin{tabular}{|c|c|c|c|c|}
\hline & \multicolumn{4}{|c|}{ Dependent Variable: SARS Incidence Rate per 100,000 } \\
\hline & $(1)$ & $(2)$ & (3) & (4) \\
\hline Monthly domestic household income for the median & $\begin{array}{c}-1.473 * * \\
(0.554)\end{array}$ & $\begin{array}{c}-1.186^{* *} \\
(0.584)\end{array}$ & $\begin{array}{l}-1.156 \\
(1.317)\end{array}$ & $\begin{array}{l}-1.878^{*} \\
(1.118)\end{array}$ \\
\hline Log $\%$ of working pop in high-contact ${ }^{\dagger}$ occupations & $\begin{array}{l}84.583 \\
(70.656)\end{array}$ & $\begin{array}{l}121.207 \\
(75.908)\end{array}$ & $\begin{array}{l}84.475 \\
(70.604)\end{array}$ & $\begin{array}{l}82.151 \\
(71.123)\end{array}$ \\
\hline Log $\%$ of students and workers who take public transportation & $\begin{array}{l}62.964 \\
(40.171)\end{array}$ & $\begin{array}{l}43.756 \\
(41.970)\end{array}$ & $\begin{array}{l}61.582 \\
(40.483)\end{array}$ & $\begin{array}{l}66.620 \\
(41.307)\end{array}$ \\
\hline$=1$ if estate facilities (e.g., health club) are available & $\begin{array}{c}86.640 * * * \\
(17.970)\end{array}$ & $\begin{array}{c}89.733^{* * *} \\
(18.271)\end{array}$ & $\begin{array}{c}86.354 * * * \\
(17.968)\end{array}$ & $\begin{array}{c}86.778 * * * \\
(18.032)\end{array}$ \\
\hline Average no. of floors per block & $\begin{array}{c}1.317 \\
(0.828)\end{array}$ & $\begin{array}{l}1.380^{*} \\
(0.828)\end{array}$ & $\begin{array}{l}1.287 \\
(0.835)\end{array}$ & $\begin{array}{l}1.336 \\
(0.833)\end{array}$ \\
\hline Log $\%$ of household with owner-occupiers, with or without a mortgag & -- & $\begin{array}{l}88.937 \\
(60.663)\end{array}$ & -- & -- \\
\hline Household income interquartile range & -- & -- & $\begin{array}{l}-0.306 \\
(1.162)\end{array}$ & -- \\
\hline Personal income interquartile range & -- & -- & -- & $\begin{array}{l}0.528 \\
(1.248)\end{array}$ \\
\hline No. of observations & 293 & 294 & 294 & 294 \\
\hline
\end{tabular}

1 Standard errors in parentheses

$2 *$ significant at $10 \% ; * *$ significant at $5 \% ; * * *$ significant at $1 \%$

$\dagger$ High-contact occupations include Service Workers \& Shop Sales Workers, Managers \& Administrators and (Associate) Professionals. Please see text for more details. 
Bucchianeri: Is SARS a Poor Man's Disease?

Table 6: Heteroskedasticity

\begin{tabular}{|c|c|c|c|c|c|c|}
\hline \multirow{3}{*}{$\begin{array}{l}\text { Restriction on the Error Term Variance } \sigma_{\mathrm{i}}^{2} \\
\left(\mathrm{~T}_{\mathrm{i}}=\text { total number of flats in estate } i\right)\end{array}$} & \multicolumn{6}{|c|}{ Dependent Variable: No. of SARS cases per 100,000} \\
\hline & \multicolumn{2}{|c|}{$\sigma_{\mathrm{i}}=\sigma^{*} \mathrm{~T}_{\mathrm{i}}^{-0.5}$} & \multicolumn{2}{|c|}{$\sigma_{\mathrm{i}}=\sigma^{*} \mathrm{~T}_{\mathrm{i}}^{\delta}$} & \multicolumn{2}{|c|}{$\sigma_{\mathrm{i}}=\sigma+\omega \mathrm{T}_{\mathrm{i}}$} \\
\hline & (1) & $(2)$ & (3) & (4) & $(5)$ & (6) \\
\hline Median monthly household rent for renting domestic households & $\begin{array}{c}-6.981 * * * \\
(1.747)\end{array}$ & $\begin{array}{c}-5.473 * * * \\
(1.765)\end{array}$ & $\begin{array}{c}-7.842 * * * \\
(2.220)\end{array}$ & $\begin{array}{c}-6.161^{* * *} \\
(2.104)\end{array}$ & $\begin{array}{l}-7.581 * * * \\
(2.205)\end{array}$ & $\begin{array}{c}-5.660 * * * \\
(2.120)\end{array}$ \\
\hline Log $\%$ of working pop in high-contact ${ }^{\dagger}$ occupations & $\begin{array}{l}215.263 * * * \\
(66.951)\end{array}$ & $\begin{array}{c}76.535 \\
(66.770)\end{array}$ & $\begin{array}{l}116.543 \\
(87.879)\end{array}$ & $\begin{array}{c}31.537 \\
(83.771)\end{array}$ & $\begin{array}{l}114.047 \\
(89.581)\end{array}$ & $\begin{array}{c}20.565 \\
(88.691)\end{array}$ \\
\hline$\%$ of students and workers who take public transportation & -- & $\begin{array}{l}1.514^{* *} \\
(0.768)\end{array}$ & -- & $\begin{array}{l}1.716^{*} \\
(0.959)\end{array}$ & -- & $\begin{array}{l}1.903^{*} \\
(1.005)\end{array}$ \\
\hline Average no. of floors per building & -- & $\begin{array}{c}0.844 \\
(0.835)\end{array}$ & -- & $\begin{array}{c}1.954 \\
(1.072)^{*}\end{array}$ & -- & $\begin{array}{c}1.679 \\
(1.135)\end{array}$ \\
\hline$=1$ if estate facilities (e.g., health club) are available & -- & $\begin{array}{c}79.697 * * * \\
(17.799)\end{array}$ & -- & $\begin{array}{c}71.019 * * * \\
(19.197)\end{array}$ & -- & $\begin{array}{c}72.364 * * * \\
(20.492)\end{array}$ \\
\hline$\delta$ & -- & -- & $\begin{array}{l}-0.087 \\
(0.082)\end{array}$ & $\begin{array}{c}-0.199 * * \\
(0.082)\end{array}$ & -- & -- \\
\hline$\omega$ & -- & -- & -- & -- & $\begin{array}{l}-0.003 \\
(0.002)\end{array}$ & $\begin{array}{c}-0.004 * * * \\
(0.001)\end{array}$ \\
\hline No. of observations & 292 & 292 & 292 & 292 & 292 & 292 \\
\hline
\end{tabular}

$2 *$ significant at $10 \% ; *$ significant at $5 \% ; * *$ significant at $1 \%$

† High-contact occupations include Service Workers \& Shop Sales Workers, Managers \& Administrators and (Associate) Professionals. Please see text for more details. 
Figure 1: Incidence of SARS Cases by District

(per 10,000 residents)

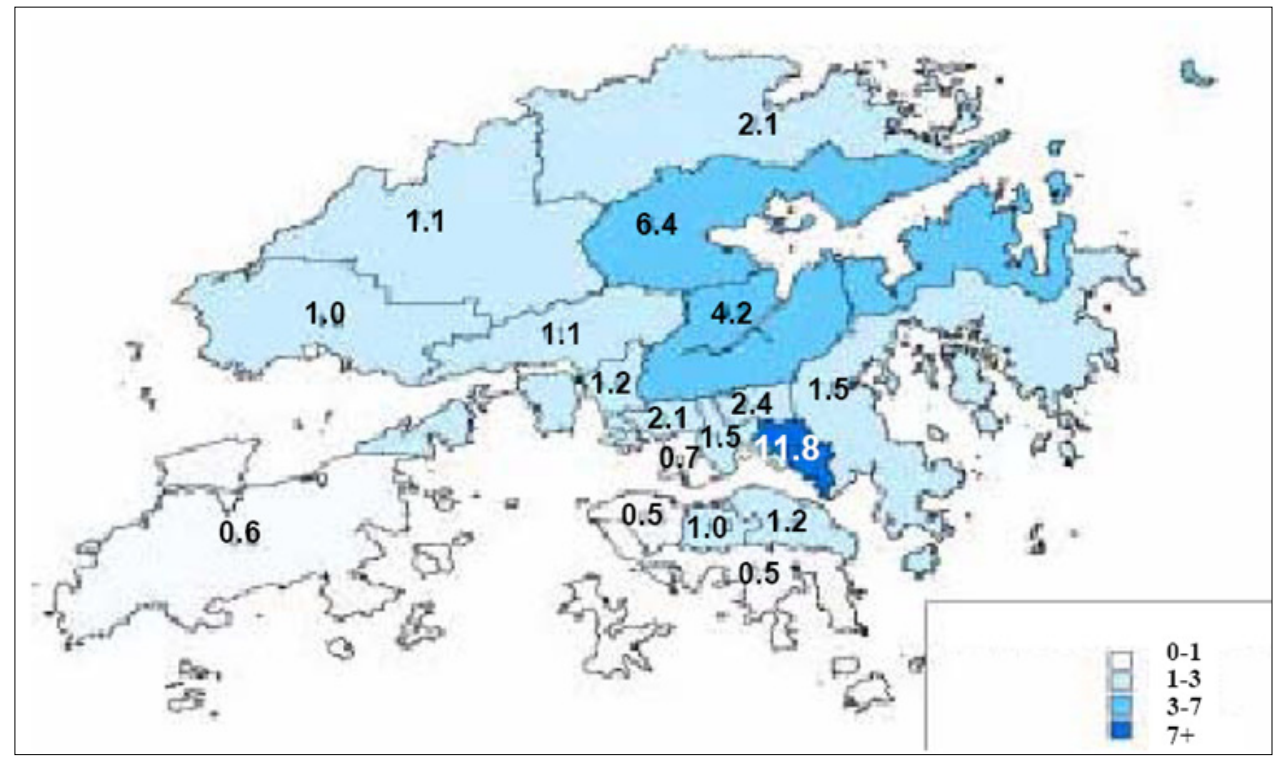

Source: HK Department of Health. SARS Bulletin, 13 June, 2003.

\section{Figure 2: Timeline of the 2003 SARS Epidemic in Hong Kong}

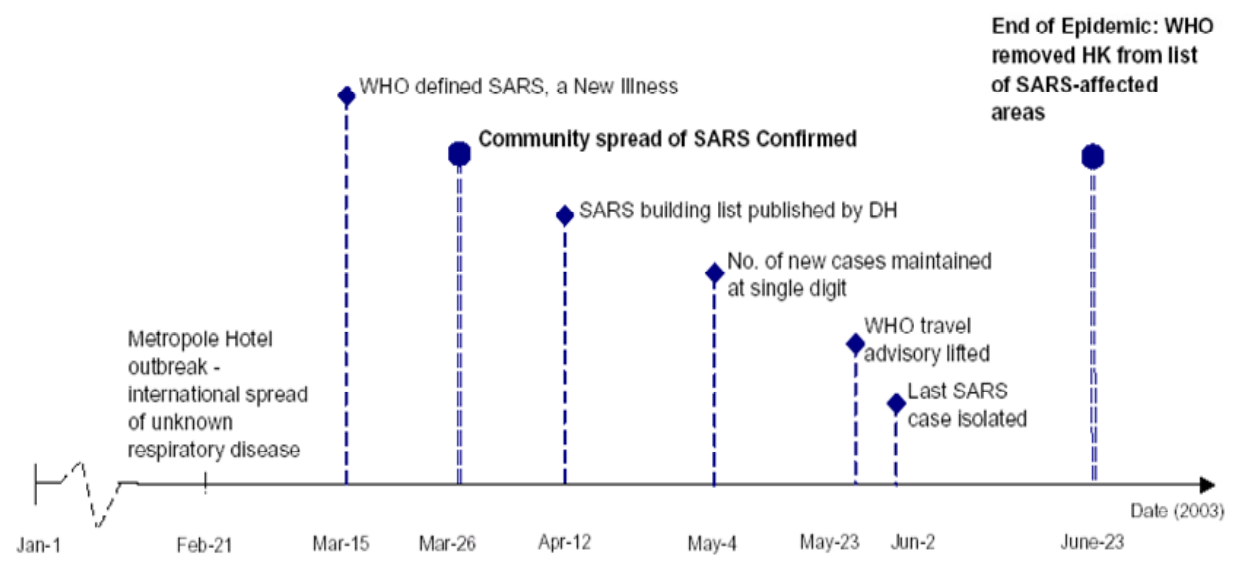

Source: Wong (2004).

DOI: 10.2202/1558-9544.1209 
Bucchianeri: Is SARS a Poor Man's Disease?

Figure 3: Estimated vs. Actual District-level SARS Incidence Rates (per 100,000)

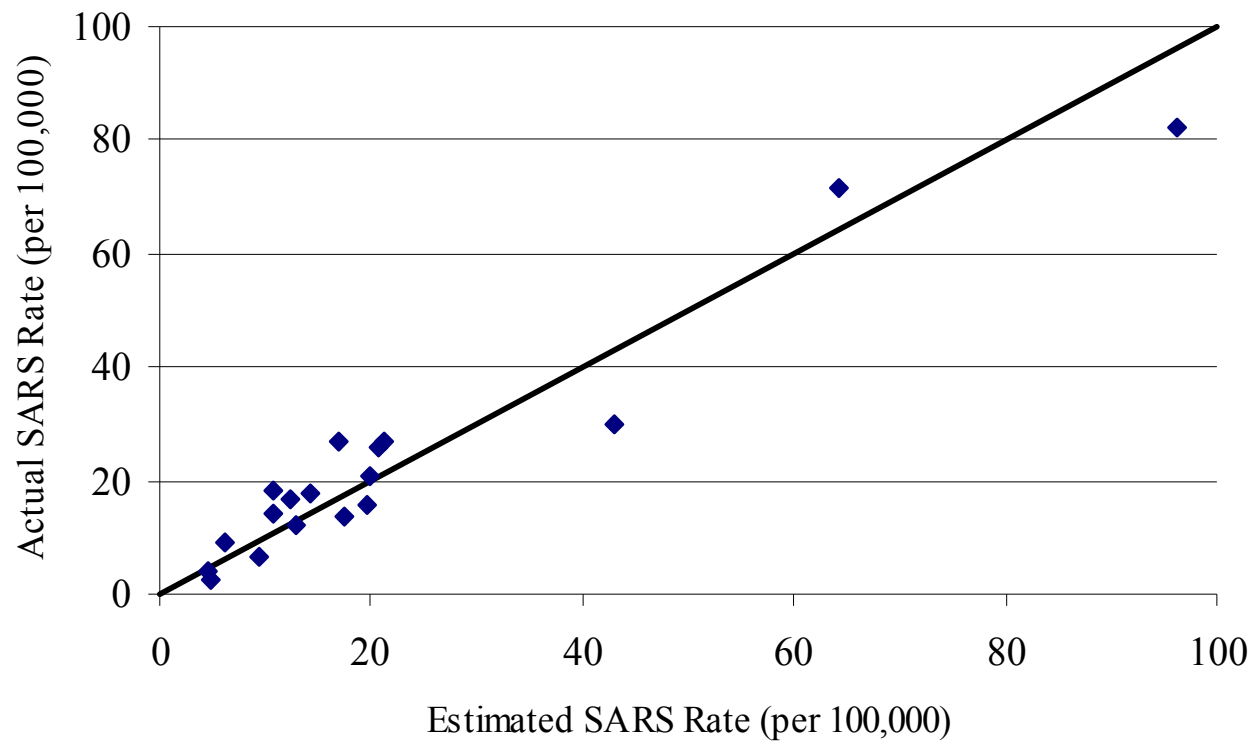

*straight line indicates the 45 degree line

\section{Appendix: Model Specification and Heteroskedasticity}

\section{A. Restrictions of the Tobit Model}

A more general approach to study the impact of various factors on the spread of SARS is to distinguish between the impact of those factors on whether a housing estate is affected by SARS at all, and on how severely it is affected, conditional on it being affected. Following Cragg (1971) and Lin and Schmidt (1984), these two relationships can be expressed as follows:

$$
\begin{aligned}
& \operatorname{Pr}\left(\text { SARSP }_{i} \leq 0\right)=1-\boldsymbol{\Phi}\left(\mathrm{X}_{\mathrm{i}} \beta_{1}\right) \\
& \operatorname{Pr}\left(\text { SARSP }_{\mathrm{i}}>0\right)=\boldsymbol{\Phi}\left(\mathrm{X}_{\mathrm{i}} \beta_{1}\right) \\
& \operatorname{Pr}\left(\text { SARSP }_{\mathrm{i}}=\mathrm{y}_{\mathrm{i}} \mid \mathrm{SARSP}_{\mathrm{i}}>0\right) \sim \mathrm{N}\left(\mathrm{X}_{\mathrm{i}} \beta_{2}, \sigma^{2}\right),
\end{aligned}
$$

where SARSP $_{i}$ is the SARS incidence rate. $\boldsymbol{\Phi}$ refers to the standard normal cumulative density function, and $\mathrm{N}(\cdot)$ the normal distribution. $\mathrm{X}_{\mathrm{i}}$ are the explanatory variables. (5) can be estimated by the Probit model, and (6) by the 
truncated regression model. The Tobit model imposes the condition that $\beta_{1}=\beta_{2} / \sigma$ and maximizes the following likelihood function:

$$
\begin{aligned}
& \operatorname{Pr}\left(\operatorname{SARSP}_{\mathrm{i}}=0\right)=1-\boldsymbol{\Phi}\left(\mathrm{X}_{\mathrm{i}} \beta / \sigma_{\mathrm{i}}\right) \\
& \operatorname{Pr}\left(\mathrm{SARSP}_{\mathrm{i}}=\mathrm{y}_{\mathrm{i}} \mid \mathrm{SARS}_{\mathrm{i}}=1\right)=1 / \sigma_{\mathrm{i}} * \phi\left(\mathrm{y}_{\mathrm{i}}-\mathrm{X}_{\mathrm{i}} \beta / \sigma_{\mathrm{i}}\right) / \boldsymbol{\Phi}\left(\mathrm{y}_{\mathrm{i}} \beta / \sigma_{\mathrm{i}}\right),
\end{aligned}
$$

where $\phi$ the standard normal probability density function. If this condition is not satisfied, the Tobit model is misspecified. In results not shown here, the truncated regression and the Probit models are estimated separately and a log-likelihood test is performed following Greene (2000). For all regressions presented in this paper the null hypothesis that the Tobit restriction is valid is not rejected at $1 \%$ level. Results are available upon request.

\section{B. Heteroskedasticity}

One way to correct for heteroskedasticity is to estimate and test some assumption on the error term variance, $\sigma_{i}^{2}$. Note that the estate-level SARS incidence rate is an average of 1-0 values, defined by whether a resident is infected by SARS or not. This gives rise to an inverse relationship between $\sigma_{i}^{2}$ and the number of flats $\left(\mathrm{T}_{\mathrm{i}}\right)$ :

$$
\sigma_{\mathrm{i}}=\sigma * \mathrm{~T}_{\mathrm{i}}^{\delta}
$$

The weighted Tobit regressions presented in this paper restricts $\delta$ to be 0.5 (Table 6, columns 1 and 2). In columns 3 and 4 I relax this assumption.

Lastly, one can model a linear relationship between $\sigma_{i}$ and all or some of the explanatory variables (Maddala, 1983; Rutemiller and Bowers, 1968). I experiment with various specifications and the total number of flats seems to have the most robust relationship with $\sigma_{\mathrm{i}}$ :

$$
\sigma_{\mathrm{i}}=\sigma+\omega \mathrm{T}_{\mathrm{i}}
$$

A test of heteroskedasticity amounts to a test of $\omega=0$. Note that columns 3 and 5 suggest the absence of heteroskedasticity because neither $\delta$ nor $\omega$ is significant. However, columns 4 and 6 indicate the opposite. $\delta$ is estimated at 0.20 in column 4 , giving support to the specification of column 2 , which is equivalent to the weighted Tobit model. All regressions discussed in this paper are replicated without restricting the value of $\delta$ in (8) and similar results are obtained. 
Bucchianeri: Is SARS a Poor Man’s Disease?

\section{References}

Asian Development Bank 2003a. Assessing the impact and cost of SARS in developing Asia.

Asian Development Bank 2003b. Action plan to address outbreak of severe acute respiratory syndrome (SARS) in Asia and the Pacific.

Astell C., et. al 2005. Severe Acute Respiratory Syndrome (SARS): A year in Review. Annual Review of Medicine 56: 357 - 381.

Brunner E. 1997. Socioeconomic determinants of health: Stress and the biology of inequality. British Journal of Medicine 314: 1472-1476.

Case A. 1991. Spatial patterns in household demand. Econometrica 59 (4): 953965.

Cragg J. 1971. Some statistical models for limited dependent variables with application to the demand for durable goods. Econometrica 39 (5): 829844.

Currie J, Stabile M. 2003. Socioeconomic status and child health: Why is the relationship stronger for older children? American Economic Review 93 (5): 1813-1823.

Deaton A.1997. The Analysis of Household Surveys: A Microeconometric Approach to Development Policy. World Bank: Washinton D.C.

Deaton A. 2002. Policy implications of the gradient of health and wealth. Health Affairs 21 (2): 13-30.

DiPasquale D, Glaeser EL. 1999. Incentives and social capital: Are homeowners better citizens? Journal of Urban Economics 45: 354-384.

Editorial. 1996. The big idea. British Medical Journal 312: 985.

Engels F. The housing question: Part two. Volksstaat 1872.

Feinstein JS. 1993. The relationship between socioeconomic status and health: A review of the literature. Millbank Memorial Fund 71 (2): 279-322.

Fung HW. 2005. Applications of GIS techniques in the Hong Kong 2006 population by-census. Prepared for the $22^{\text {nd }}$ Population Census Conference USA.

Greene WH. 2000. Econometric analysis. Prentice Hall: New Jersey.

Goldman N. Social inequalities in health: Disentangling the underlying mechanisms. Conference proceedings of the seminar on "Demography and epidemiology: frontiers in population health and aging." Georgetown University, Washington D.C. February 9-10, 2001; New York Academy of Sciences.

Gregson, Simon, Heather Waddell, Stephen Chandiwana. 2001. School education and HIV control in sub-Saharan Africa: from discord to harmony? Journal of International Development.

Hong Kong Department of Health. 2003. <www.dh.gov.hk> 
Hurd MD, Adams P, McFadden D, Merrill A, Ribeiro T. 2003. Healthy wealthy and wise? Tests for direct causal paths between health and socioeconomic status. Journal of Econometrics 112 (1): 3-56.

Lau JT, Yang X, Tsui H, Kim JH. 2003. Monitoring community responses to the SARS epidemic in Hong Kong: From day 10 to day 62. Journal of Epidemiol Community Health 57: 864-870.

Lin TF, Schmidt P. 1984. A test of the Tobit specification against an alternative suggested by Cragg. Review of Economics and Statistics 66: 174-177.

Lipstitch M, et al. 2003. Transmission dynamics and control of severe acute respiratory syndrome. Science 300: 1966-1970.

Loh C. 2004. At the epicenter: Hong Kong and the SARS outbreak. Hong Kong University Press: Hong Kong.

Maddala GS. 1983. Limited-dependent and qualitative variables in econometrics. Cambridge University Press: Cambridge, England.

Manski CF. 2000. Economic analysis of social interactions. Journal of Economic Perspectives 14 (3): 115-136.

Marmot MG. 2002 The influence of income on health: Views of an epidemiologist. Health Affairs 21 (2): 31-46.

Marmot MG, Feeney A, Shipley M, North F, Syme SL. 1995. Sickness absence as a measure of health status and functioning: From the UK Whitehall II Study. Journal of Epidemiol Community Health 49 (2): 124-130.

Marmot MG, Shipley M, Rose G. 1984. Inequalities in death-Specific explanations of a general pattern? Lancet 1 (8384): 1003-1006.

Marmot MG, Smith GD, Stansfeld S, Patel C, North F, Head J, White I, Brunner E, Feeney A. 1991. Health inequalities among British civil servants: The Whitehall II Study. Lancet 337 (8754): 1387-1393.

Meer J, Miller DT, Rosen HS. 2003. Exploring the health-wealth nexus. National Bureau of Economic Research Working Paper 9554.

Riley S, et al. 2003. Transmission dynamics of the aetiological agent of severe acute respiratory syndrome (SARS) in Hong Kong: the impact of public health interventions. Science 300: 1961-1966.

Rogot E, Sorlie PD, Johnson NJ. 1992. Life expectancy by employment status, income, and education in the national longitudinal mortality study. Public Health Rep 107: 457-461.

Rutemiller HC, Bowers DA. 1968. Estimation in a heteroskedastic regression model. Journal of the American Statistical Association 63: 552-557.

Schnittker J. 2004. Education and the changing shape of the income gradient in health. Journal of Health and Social Behavior 45 (3): 286 - 305. 
Bucchianeri: Is SARS a Poor Man’s Disease?

Tang C and Wong C. 2003. An outbreak of the Severe Acute Respiratory Syndrome: Predictors of health behaviors and effect of community prevention measures in Hong Kong, China. American Journal of Public Health 93 (11): 1887-1888.

Waldmann RJ. 1992. Income distribution and infant mortality. Quarterly Journal of Economics 107: 1283-1302.

Wong G. 2008. Has SARS infected the property market? Evidence from Hong Kong. Journal of Urban Economics, Vol. 63, pp. 74-95.

World Health Organization 2003. Consensus document on the epidemiology of SARS. 